\title{
Analysis of Performance Evaluation of Regional Government Management in Supporting Digital Economic Era
}

\author{
Atik Andhayani* \\ Polinema \\ Malang, Indonesia \\ *atikassa75@gmail.com
}

\author{
Sutrisno T, Ali Djamhuri, Rosidi Rosidi \\ Brawijaya University \\ Malang, Indonesia
}

\begin{abstract}
In entering the era of the digital economy Indonesia accelerates its economic development wherein in this case Indonesia must utilize the existing potential both in terms of the potential of information and communication technology infrastructure as well as from human resources. The proportion of young people numbering more than $25 \%$ of the total 260 million people of Indonesia in 2017, the growth of Micro, Small and Medium Enterprises (MSMEs) supporting Gross Domestic Product (GDP) should be utilized specifically to accelerate regional development. Performance Evaluation of Local Government Organizations (EKPPD) can see readiness in supporting the era of the digital economy in the region. This research was conducted by means of quantitative descriptive statistical data about local government from the ministry and the Central Statistics Agency. The results showed that the value of EKPPD influences the readiness of the government especially the Human Development Index (HDI) and Indonesia's economic ecosystem seen from the GRDP which supports regional fiscal dependencies. Regional readiness is also supported by human resources, infrastructure and society in facing the digital era.
\end{abstract}

Keywords: EKPPD, GDP per capita, HDI, fiscal dependency, digital economy

\section{INTRODUCTION}

Decentralization in Indonesia, which began in 2001, transferred various kinds of central government authorities and responsibilities to regional governments (Pemerintah daerah/Pemda). Law No. 32 of 2004 (Law No. 32/2004) concerning Regional Government affirms the authority of the Regional Government to regulate and manage its own government affairs based on the principle of autonomy. As an implication, the role of local governments in providing public services and achieving national development goals is even greater. Regions will have little ability if they are only assigned to follow central government policies. Decentralization provides increased responsibilities, resources, and capacity of local institutions so that the principle of democracy can be realized with the opportunity of the people to participate in governance and development. In addition, local governments must also be accountable to the local community and to higher levels of government [1]. Systematic monitoring, evaluation and measurement of local government performance are needed to measure progress. Pursuant to Government Regulation No.6 of 2008 concerning Guidelines for Evaluating the Management of Regional Government, it is stated that one of the evaluations of the administration of regional government is in the form of an Evaluation of the Performance of the Regional Government Management (EKPPD) [2]. The aim of the EKPPD is to see the extent to which regional governments can meet the objectives of regional autonomy, such as how local governments improve the welfare of their communities, improve the education and health of citizens, and so on. EKPPD there are indicators used to assess performance called Key Performance Indicators (IKK). EKPPD assessments are good then the performance of regional governance is in line with national development ideals, both in terms of administration, financial management and public services. The problem of governance, especially in local governments so far, is that the most widely complained of institutions by the community is the local government. The process of governance in regions that are not transparent creates opportunities for a lot of corruption [3]. The government is demanded to be more responsive and transparent in providing services to the community.

The model of public services carried out through an electronic system or e-government was conceived to help these demands. E-government supports the management of government that is more efficient, transparent and accountable so that it makes it easier for the public to access and criticize government policies. Along with the development of technology, the needs of the community are also increasing so that it raises new demands. Indonesian society is sociologically literacy level towards Computer Information Technology (especially internet) is very high. Therefore, the community as users of government services by implementing e-government in the administration of local government, is expected to adjust more quickly [4]. The development of internet technology achieved a very rapid development so that it affected the development of e-government of the local government of Indonesia. Internet applications that are used for e-commerce in this case developed to become the use of internet applications in the government environment which became known as egovernment. Development of e-government applications requires substantial funding so readiness is needed in terms of the human resources of government officials and the 
community. Surveys in several countries show that there is a tendency for government officials not to carry out activities online, because they prefer traditional service methods in the form of face-to-face, correspondence or telephone [5]. We must learn from the causes of e-government failure in a number of countries caused by several factors, namely: the unpreparedness of human resources, facilities and infrastructure of information technology, as well as the lack of attention from those directly involved. E-government is the use of information and telecommunications technology for efficient and effective government administration, as well as providing transparent and satisfying services to the public. All government organizations will be affected by the development of e-government.

Looking at the dynamics of the global and domestic economy, Indonesia's development challenges and targets to be achieved as well as various policies that will be pursued in the next few years are generally directed to stimulate the economy and realize prosperity through revenue optimization, increasing the quality of spending, as well as maintaining fiscal sustainability. Local governments play a role in the economy, namely the optimization of revenues, especially from the original local revenue from fiscal dependencies that gradually do not depend on the central government. The development of regional trade from all aspects and sectors that can be explored, for example tourism, crafts at MSMEs must be encouraged to encourage regional fiscal dependencies. The development of information technology penetrated to make the world of commerce develop very rapidly which gave rise to the potential of the e-commerce industry in Indonesia. Growth in the value of online business sales in the country each year increased by 40 percent. There are about 93.4 million internet users and 71 million smartphone users in Indonesia. Not just to find information and chat, people in big cities are now making the internet, especially e-commerce, as part of their lifestyle. Consumptive behavior of tens of millions of middle class people in Indonesia is the reason why e-commerce in Indonesia will continue to grow. Talking about this industry is not merely talking about buying and selling goods and services via the internet. But there are other industries that are connected in it, such as the delivery of logistics or services, telecommunications providers, smart device manufacturers, and others. This is what makes the e-commerce industry must be guarded to be able to drive the pace of the national economy. This business has enormous value, but unfortunately until now there is no specific regulation governing this online business. At the end of 2014 the business value of Indonesia's e-commerce industry reached USD 12 billion. The Government of Indonesia, under the coordination of the Coordinating Ministry for Economic Affairs, collaborates with the Ministry of Communication and Information and related ministries / institutions, stakeholders from associations and ecommerce entrepreneurs, as well as world-class consultant Ernst \& Young, working together in preparing a good ecosystem to develop local e-commerce industry. After conducting workshops and roadshows conducted by ministries and industry actors, a draft of the Indonesia E-commerce Roadmap was created which is currently in the finalization stage. Issues around e-commerce must be solved and the potential of the e-commerce growth must be supported [6]. The role of regional government is needed in supporting digital economy, because it is related to the potential of human resources and has an effect on gross regional per capita domestic income (GRDP per capita). Human resources that can compete in the digital economy era can benefit from the growth of this technology, but on the contrary, can also cause a lot of unemployment [7].

This study presents an EKPPD analysis supported by HDI, Gross Regional Domestic Product, and regional fiscal dependencies that can drive economic growth in the current digital era in a local government. Previous research has not linked the aforementioned matters, several studies have put forward just about economic and fiscal dependencies such as the study in Jambi City that fiscal dependencies support regional economic growth [8]. Research on economic performance in 2005 and 2006, found that local government revenue, exports, imports, GDP, and income of family have a positive effect on the economic performance of local governments in China [9]. The implementation of EKPPD in Indonesia with the following table:

TABLE I. GROUPING OF EKPPD INDEX AND ACHIEVEMENT STATUS

\begin{tabular}{|l|l|l|}
\hline \multicolumn{1}{|c|}{ No } & \multicolumn{1}{|c|}{ Index EKPPD } & \multicolumn{1}{|c|}{ Achievement Status } \\
\hline 1 & $3,00<$ Score $\leq 4,00$ & Very High \\
\hline 2 & $2,00<$ Score $\leq 3,00$ & High \\
\hline 3 & $1,00<$ Score $\leq 2,00$ & Medium \\
\hline 4 & $0,00 \leq$ Score $\leq 1,00$ & Low \\
\hline
\end{tabular}

Source: Ministry of Home Affairs EKPPD 2016 Year (data processed)

\section{METHODS}

Data analysis is one of the research processes conducted after all the necessary data is obtained. The analysis was carried out in order to solve the problem under study. Sharpness and accuracy in the use of analytical tools determine the accuracy of the conclusion. Therefore, data analysis activities are activities that cannot be ignored in the research process. Errors in determining the analysis tool can be fatal to the conclusions generated where this will have an even worse impact on the use and application of the results of these studies. Thus, the knowledge and understanding of various analytical techniques is absolutely necessary for a researcher so that the results of his research are able to make a meaningful contribution to solving problems while at the same time being scientifically responsible. Broadly speaking, data analysis techniques are divided into two parts, namely quantitative and qualitative analysis. Thing distinguishes the two techniques lies only in the type of data. For data that is qualitative in nature (cannot be quantified), the analysis used is qualitative analysis, whereas for data that can be quantified, it can be analyzed quantitatively, even it can also be analyzed qualitatively.

This research method uses descriptive quantitative with secondary data analysis approach. Descriptive analysis is a statistic used to analyze data by describing or describing the data that has been collected as it is without intending to make conclusions that apply to the public or generalization [10]. Descriptive statistics is a part of statistics that studies how to collect data and present data so that it is easy to understand, only relates to describing or providing information about a data or situation, serves to explain the conditions, symptoms, or 
problems so that drawing conclusions on descriptive statistics (if exist) only aimed at existing data sets [11]. The conclusion is that descriptive analysis is part of the statistics used to describe or describe data without intending to make conclusions or make conclusions but only explain the group of data. In this study, this analysis utilizes secondary data as the main data, which uses information needed from agencies or institutions such as the Central Statistics Agency, certain departments or institutions and then conducts appropriate statistical tests to obtain information, then is processed systematically and objectively. Things that need to be considered in utilizing this secondary data is on the validity and reliability of the data to be used. Some steps that need to be done in the research process using secondary data analysis. These steps are: formulating the problem, determining the unit of analysis, testing or re-checking the availability of data, conducting a literature study, collecting data, processing secondary data, presenting data and providing interpretation, and compiling reports on research results.

\section{RESULTS}

City government officials and decision makers must ensure that there is financial, technical and structural support, which requires sound political leadership and political will committed to e-government. Legislative and executive actions to ensure that transformative efforts have a legal basis, a positive attitude towards transformational governance ideas and practices must be maintained among city government officials and officials [12]. The development and progress of Indonesia's digital economy is greatly supported by local governments. Opportunities for progress in the digital economy are very touching if directly carried out by MSMEs in all corners of the local government of Indonesia with the specialness and characteristics of each region. EKPPD as an evaluation of the implementation of regional government can reflect how HDI as human resources, GRDP per capita as the average income of the people, and fiscal dependency as the ability of the region for independence in developing its region. All of these things can develop along with the current rapid information technology. Each region must pay attention to the supporting factors of the EKPPD in supporting the digital economic era by increasing HDI, per capita GRDP and for the fiscal dependencies in the five regional governments mentioned below from the lowest values for the average of 2013 to 2016, without ignoring other regions.

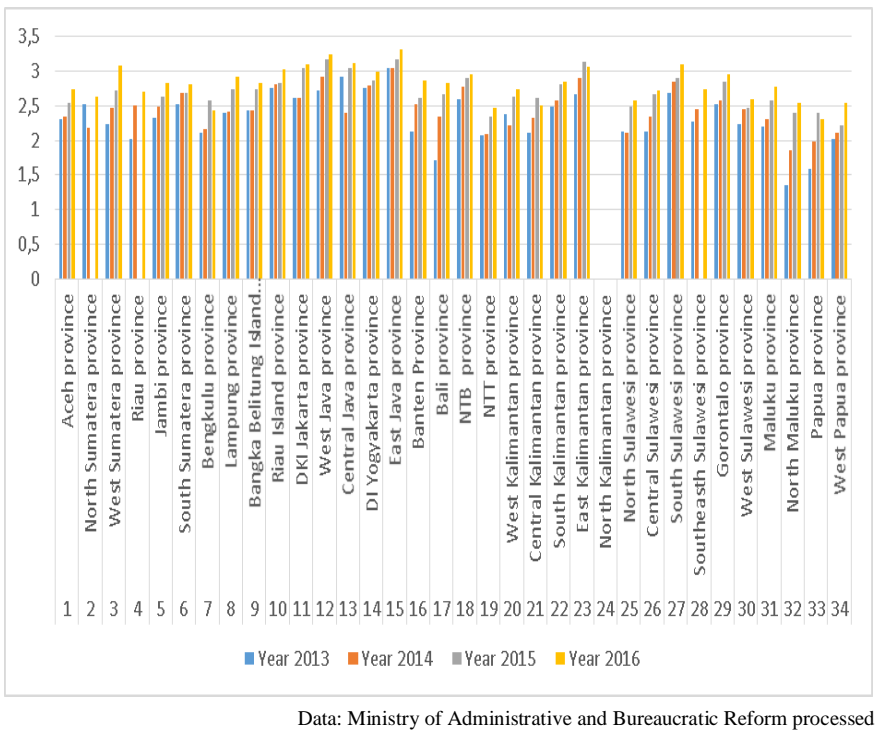

Fig. 1. EKPPD's chart of the regional government of the Provinces of Indonesia in 2013-2016.

The chart shows that the average EKPPD value has increased from 2013 to 2016. Overall evaluation for 2013 to 2016 obtained five provincial governments with an average of the lowest values as follows: North Maluku province, Papua province, West Papua province, NTT province and Bengkulu province. This shows that the five regions have not carried out good governance including the achievement of performance at the level of policy makers and the implementation of policies using Key Performance Indicators (IKK). In EKPPD there are things that reflect the digital economic supporting factors of a local government, including IPM, PDRBper per capita and fiscal dependencies. Supporting EKPPD in supporting the regional government economy can be seen among others from the following explanation:

\section{A. The Growth of the Human Development Model in Indonesia}

According to UNDP (1990) human development is formulated as an enlarging the choices of people, which can be seen as a process of efforts towards "expanding choices" and at the same time as the level achieved from these efforts. Human development can also be seen from the side of the actors or targets to be achieved. UNDP sees human development as a kind of "model" of development of the population, and by the population, which can be explained as follows: about the population in the form of investments in education, health, and other social services; for the population in the form of creating employment opportunities through expansion (domestic economic growth); by the population, namely the population in determining human dignity by participating in the political and development process. UNDP measures the level of fulfillment of the three elements above, compiles a composite index based on 3 (three) indicators, namely: life expectancy at age 0: eo, adult literacy rate (lit) and mean years of schooling (MYS) and purchasing power parity - which are measures of opinion adjusted for purchasing power parity. The first indicator measures "longevity and health", the next two indicators measure "knowledge and skills", while the last indicator 


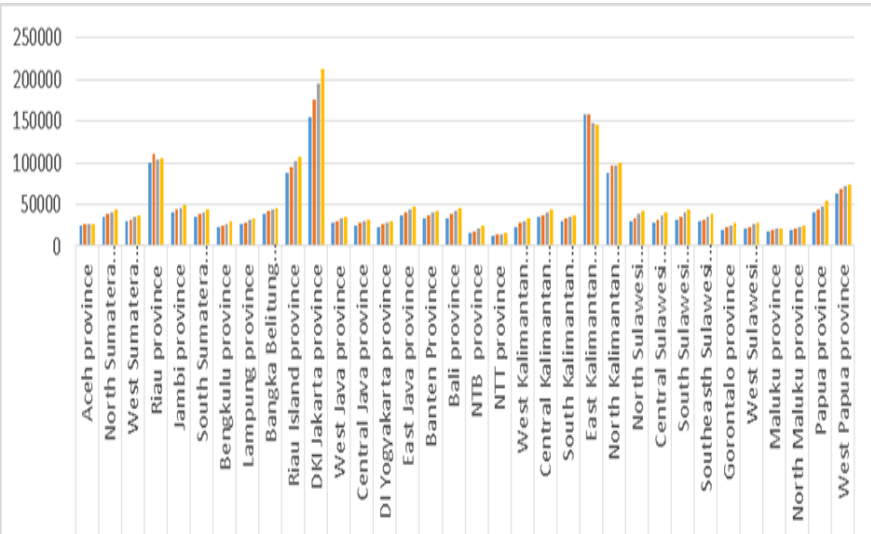

12345678910111213141516171819202122232425262728293031323334

- Year 2013 -Year 2014 - Year 2015 -Year 2016

Data: BPS processed

Fig. 3. GRDP's chart per capita of provincial governments in Indonesia for 2013-2016.

The highest GDP's chart in 2013-2016 was DKI Jakarta province and the five lowest regions on average from 20132016 are as follows: NTT province, Maluku province, NTB province, North Maluku province and Gorontalo province. This shows that the five lowest regions have not yet achieved economic equality, so it should be encouraged to advance the regional economy to be able to follow the development of the current digital economic era.

\section{Local Government Fiscal Dependencies}

The implication of fiscal decentralization is that its implementation will not be able to directly improve the welfare of the community if the local government ignores the regional economic capacity. Economic capacity can be increased by increasing economic growth. Local macroeconomic policies in this condition are oriented towards growth and not only pursuing an increase in regional income [15]. Previous research proves the existence of empirical evidence that the positive impact of low-level corrupt local government spending on service access is to some extent when district dependence on intergovernmental transfers increases [16]. The digital economy is very closely related to broad economic activities and the role of local communities so that the local government must maintain economic stability and always try to spur economic growth as an important factor for increasing fiscal dependency.

\section{B. Regional Government GRDP}

GRDP per capita is a calculation of the total increase in goods and services in a certain year in a certain period and a certain region is flattened to the total population in the region. Equitable results of economic growth must also be enjoyed by the entire population, not only enjoyed by a group of people. In the economic development of an area of income distribution will cause a higher income gap, but as the economy matures, the income gap will decrease slowly after passing the peak [14]. PDRB data per capita of provincial governments in Indonesia for 2013-2016. 


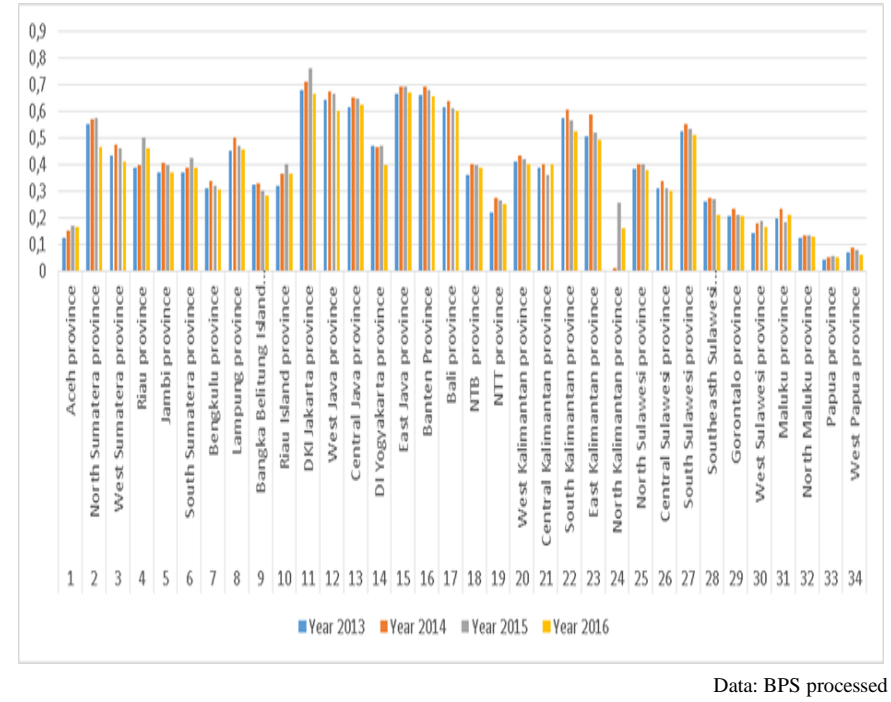

Fig. 4. Fiscal Dependency's chart for 2013-2016 of all provincial governments in Indonesia.

The highest fiscal dependency's chart in 2013-2016 were DKI Jakarta provinces and the five lowest regions on average from 2013-2016 as follows: Papua province, West Papua province, North Maluku province, West Sulawesi province, Aceh province.

\section{CONCLUSION}

The OECD team emphasizes that the digital economy cannot be separated from technology and vast influence, but covers all sectors. Digital economy is the merging of several technologies, namely general purpose technologies (GPTs) with various economic and social activities carried out through the internet and related technologies. This includes physical infrastructure, which is based on digital technology (broadband lines, routers), devices used to access (Google, Salesforce), and applications that have power (IoT, data analytics, and cloud computing) [17]. The digital economy era requires the support of resources, structurally forming economics, processes in the economy and business models [18]. The development of the digital economy cannot be separated from the influence of technology. Technology can make it easier for people to access a service or replicate human intelligence so as to make the process of business, manufacturing, and decision-making mechanisms easier. The presence of the digital economy has changed the structure of the existing system. The regional government in particular must encourage the growth of MSME business players who are able to advance to become big business actors, even to international level. The growth of online businesses is so rapid, the people of Indonesia will get positive benefits in the economy such as growth in welfare, growth in new jobs and others. Performance Evaluation of Local Government Administration (EKPPD) should be able to evaluate to support the readiness of local governments in the era of the digital economy. Some areas can be pushed towards progress if there are still weak in the HDI, GRDP and fiscal dependencies. The strategy of the regional government in developing digital economy must be understood more thoroughly, namely the development of technology and infrastructure as well as the preparation of a development strategy for Indonesia's economic order and ecosystem that is adaptive to development. In the future, Indonesia will no longer be merely a target for international business markets, but instead can become capable e-commerce entrepreneurs reaching out to foreign markets.

\section{REFERENCES}

[1] M. Mangantar, "An Analysis of the Government Financial Performance Influence on Community Welfare in North Sulawesi Province Indonesia," Int J Econ Financ Issues, vol. 8, pp. 137-43, 2018.

[2] R. Mayasari and J. Febriantoko, "See More: Evaluation of Work Programs and Financial Performance of Local Government in Indonesia Through Cipp Model," Int J Contemp Res Rev, vol. 9, pp. 21169-78, 2018.

[3] M. Surianti and A.R. Dalimunte, "The Implementation of Performance Based Budgeting In Public Sector (Indonesia Case: A Literature Review)," Int J Dev Emerg Econ, vol. 5, pp. 52-67, 2017.

[4] T.S. Kurnia, U. Rauta, and A. Siswanto, "E-Government Dalam Penyelenggaraan Pemerintahan Daerah Di Indonesia," Masal Huk, vol. 46, p. $170,2018$.

[5] Y. Chen and Y. Kim, "Adoption of E-Government Services by Small Municipalities," Int J Organ Theory Behav, vol. 36, 2018.

[6] G.I. Zekos, "MNEs, Globalisation and Digital Economy: Legal and Economic Aspects," Managerial Law, vol. 45, 2003.

[7] P. Beynon-Davies, "Models for e-government," Transform Gov People, Process Policy, vol. 1, pp. 7-28, 2007.

[8] M. Ariansyah, A. Amir, and E. Achmad, "Tingkat Ketergantungan Fiskal dan Hubungannya dengan Pertumbuhan Ekonomi di Kota Jambi," J Perspekt Pembiayaan Dan Pembang Drh, vol. 1, pp. 159-64, 2014.

[9] M.I. Lin, Y.D. Lee, and T.N. Ho, "Applying integrated DEA/AHP to evaluate the economic performance of local governments in China," Eur J Oper Res, vol. 209, pp. 129-40, 2011.

[10] Sugiyono, Metode Penelitian Bisnis (Pendekatan Kuantitatif, Kualitatif dan R\&D). 18th ed. Bandung: CV Alfabeta, 2014.

[11] I. Hasan, Pokok-pokok Materi Statistik 1 (Statistik Deskriptif). 2nd ed. Jakarta: PT Bumi Aksara, 2003.

[12] E. Batara, A. Nurmandi, T. Warsito, and P. Ulung, "Are Government Employees Adopting Local E-Government Transformation? The Need For Having The Right Attitude, Facilitating Conditions and Performance Expectations," Transform Gov People, Process Policy, vol. 28, 2017.

[13] R. Maulana and P. Ari Bowo, "Pengaruh Pertumbuhan Ekonomi, Pendidikan DanTeknologi Terhadap IPM Provinsi Di Indonesia 20072011," Jejak J Econ Policy, vol. 7, pp. 134-40, 2014.

[14] D. Fatihudin and N.L. Mauliddah, "Expenditure on education, health and PDRB per capita on the gini ratio city in the East Java province of Indonesia," Int J Civ Eng Technol, vol. 10, pp. 2428-34, 2019.

[15] I.B.P. Purbadharmaja, I.B.P. Maryunani, C.F. Ananda, and D.B. Santoso, "The Implications of Fiscal Decentralization and Budget Governance on Economic Capacity and Community Welfare," Foresight, vol. 21, pp. 227-49, 2019.

[16] B.D. Lewis and A. Hendrawan, "The impact of majority coalitions on local government spending, service delivery, and corruption in Indonesia,” Eur J Polit Econ, vol. 58, pp. 178-91, 2019.

[17] B.C. Dahlman, S. Mealy, and M. Wermelinger, "DEV / DOC / WKP ( 2016 ) 6 Unclassified Authorised for publication by Mario Pezzini , Director of the OECD Development Centre," 2016.

[18] R. Bukht and R. Heeks, "Defining, conceptualising and measuring the digital economy,” Int Organ Res J, vol. 13, pp. 143-72, 2018. 